\title{
Microglia display modest phagocytic capacity for extracellular tau oligomers
}

\author{
Petra Majerova ${ }^{1 \dagger}$, Monika Zilkova $^{1,2 \dagger}$, Zuzana Kazmerova ${ }^{2}$, Andrej Kovac ${ }^{1,2}$, Kristina Paholikova $^{1}$, \\ Branislav Kovacech ${ }^{1,2}$, Norbert Zilka ${ }^{1,2^{*}}$ and Michal Novak ${ }^{1,2}$
}

\begin{abstract}
Background: Abnormal misfolded tau protein is a driving force of neurofibrillary degeneration in Alzheimer's disease. It has been shown that tau oligomers play a crucial role in the formation of intracellular neurofibrillary tangles. They are intermediates between soluble tau monomers and insoluble tau filaments and are suspected contributors to disease pathogenesis. Oligomeric tau can be released into the extracellular space and spread throughout the brain. This finding opens the question of whether brain macrophages or blood monocytes have the potential to phagocytose extracellular oligomeric tau.
\end{abstract}

Methods: We have used stable rat primary microglial cells, rat peripheral monocytes-derived macrophages, BV2 microglial and TIB67 macrophage immortalized cell lines that were challenged by tau oligomers prepared by an in vitro aggregation reaction. The efficiency of cells to phagocytose oligomeric protein was evaluated with confocal microscopy. The ability to degrade tau protein was analyzed by immunoblotting.

Results: Confocal microscopy analyses showed that macrophages were significantly more efficient in phagocytosing oligomerized tau proteins than microglial cells. In contrast to macrophages, microglia are able to degrade the internalized oligomeric tau only after stimulation with lipopolysaccharide (LPS).

Conclusions: Our data suggests that microglia may not be the principal phagocytic cells able to target extracellular oligomeric tau. We found that peripheral macrophages display a high potency for elimination of oligomeric tau and therefore could play an important role in the modulation of neurofibrillary pathology in Alzheimer's disease.

Keywords: Alzheimer's disease, Extracellular tau, Tau oligomers, Neuroinflammation, Microglia, Macrophages

\section{Background}

Neuroinflammation plays a key role in the modulation of the pathogenesis of neurodegenerative disorders such as Alzheimer's disease (AD) and related tauopathies [1-3]. In $\mathrm{AD}$, activated microglia may become neurotoxic through their increased expression of pro-inflammatory cytokines, which lead to extensive neuronal death and disease manifestation $[4,5]$. Prolonged activation of microglia might impair their lysosomal enzymatic complex and such 'frustrated phagocytes' are not able to remove AD pathological lesions [6,7]. Another study demonstrated that microglia

\footnotetext{
*Correspondence: Norbert.Zilka@savba.sk

${ }^{\dagger}$ Equal contributors

'Institute of Neuroimmunology, Slovak Academy of Sciences, AD Centre, Dubravska cesta 9, 84510 Bratislava, Slovak Republic

${ }^{2}$ Axon Neuroscience SE, Dvorakovo nabrezie 10, 81102 Bratislava, Slovak Republic
}

\section{Biomed Central}

could internalize $A \beta$ plaques but they released it back into the medium without degradation [8].

It has been hypothesized that macrophages which infiltrate the brain could be more effective in the recognition and subsequent elimination of the pathological lesions than resident microglia [9]. Simard et al. [10] showed that circulating cells such as monocytes could be responsible for effective phagocytosis and degradation of amyloid plaques in transgenic AD mice. Furthermore, peripheral macrophages were found to be particularly efficient in phagocytosing synthetic A $\beta$ peptides [11].

Distribution of activated microglia parallels that of tau deposits in human AD [12-16] and non-AD tauopathies such as tangle-predominant dementia, progressive supranuclear palsy, corticobasal degeneration and Pick's disease [17-21]. Activated microglia have been frequently present in the proximity of neurofibrillary tangles at early and late 
stages of tangle formation, which suggests a close relationship between inflammatory response and tau neurofibrillary lesions [14]. The activation of microglia linked to tau deposition has been also observed in various tau transgenic models [22-27].

Several previous studies have demonstrated that extracellular tau proteins play an important role in AD neuroinflammation [28-30]. It was shown that the oligomeric tau that represents an early stage of tangle formation can be released into the extracellular space, where it behaves as a transmissible agent, spreading tau pathology throughout the brain in a 'prion-like fashion' [31-33].

These findings raise the question of whether brain macrophages or peripheral monocytes entering the brain have the potential to phagocytose extracellular oligomeric tau and thus eliminate its toxic function. Therefore we have investigated the ability of BV2 microglia, immortalized TIB67 macrophages cell lines, peripheral blood monocytes-derived macrophages and primary microglia to phagocytose and degrade tau oligomers. Misfolded truncated tau was used as a template for tau oligomerization. Truncated tau species was identified by two monoclonal antibodies (MN423 and DC11) in the human AD brain [34-36]. The truncated tau used in this study was previously shown to induce abnormal microtubular assembly in vitro [37] and extensive neurofibrillary degeneration in vivo $[37,38]$.

In this study we found that peripheral blood monocytederived macrophages (PB-MoM) and immortalized TIB67 macrophages are more proficient in the phagocytosis and degradation of oligomerized truncated tau than primary microglial cells or immortalized BV2 microglia.

\section{Materials and methods}

\section{Expression and purification of recombinant tau protein}

Human truncated tau151-391 (numbering according to the longest human tau isoform Tau40) was expressed in Escherichia coli strain BL21(DE3) (Sigma-Aldrich, St. Louise, Missouri, United States) from a pET-17 expression vector and purified from bacterial lysates as described previously [39], except that the phosphocellulose step was omitted and size-exclusion chromatography was performed in PBS (137 mM NaCl, $2.7 \mathrm{mM} \mathrm{KCl,} 10 \mathrm{mM}$ $\mathrm{Na}_{2} \mathrm{HPO}_{4}, 2 \mathrm{mM} \mathrm{KH} \mathrm{PO}_{4}, \mathrm{pH}$ 7.4) (AppliChem GmbH, Darmstadt, Germany). Purified tau protein was stored in PBS in working aliquots at $-70^{\circ} \mathrm{C}$. The purity of tau protein was subsequently verified by gradient SDS gel electrophoresis (5 to 20\% gel), Coomassie blue staining and Western blot analysis with DC25 antibody (AXON Neuroscience SE (Bratislava, Slovakia), recognizes residues 347-354 of the longest human tau isoform Tau40). The fluorescently tagged tau protein was prepared by labelling with Alexa Fluor 546 (Invitrogen, Carlsbad, California, United States) according to the manufacturer's recommendations.
Tau filament assembly and detection of tau oligomers In vitro oligomerization of recombinant truncated tau protein (aa 151-391, $100 \mu \mathrm{M}$ ) was carried out using heparin (Sigma-Aldrich, St. Louis, Missouri, United States) as an inducer at a final concentration of $25 \mu \mathrm{M}$ in PBS (137 mM NaCl, $2.7 \mathrm{mM} \mathrm{KCl,} 10 \mathrm{mM} \mathrm{Na} \mathrm{HPO}_{4}$, $2 \mathrm{mM} \mathrm{KH} \mathrm{PO}_{4}, \mathrm{pH}$ 7.4) The reaction was performed overnight (for at least 12 hours) at $37^{\circ} \mathrm{C}$. After incubation, tau oligomers were collected by centrifugation at $100,000 \times \mathrm{g}$ for 1 hour at room temperature and the pellet was re-suspended in PBS and sonicated for $5 \mathrm{sec}-$ onds at 20\% power output using an MS72 probe of a Bandelin Sonopuls Sonifier (Bandelin, Berlin, Germany). Subsequently, $1 \mu \mathrm{M}$ aliquots were stored at $-70^{\circ} \mathrm{C}$. The oligomerization of the tau protein was verified by SDS gel electrophoresis, quantitative thioflavin T (ThT) fluorescence spectroscopy with excitation at $450 \mathrm{~nm}$ and emission at $510 \mathrm{~nm}$, and by electron microscopy.

\section{Transmission electron microscopy}

For morphological examination of in vitro oligomerized tau by electron microscopy the oligomers collected by centrifugation were dissolved in pure water (Merck Millipore, Darmstadt, Germany) and placed on carboncoated 400 mesh copper grids (Christine Gröpl, Austria) for 2 minutes. Grids were washed with pure water for 2 minutes and the tau oligomers were negatively stained with $2 \%$ uranyl acetate for 1 minute (Sigma-Aldrich, St. Louis, Missouri, United States). The stained grids were immediately analyzed using an FEI Morgagni 268 electron microscope (Czech Republic).

\section{Cell cultivation}

Mouse microglial BV2 cells (C57BL/6, purchased from ICLC, Modena, Italy) and mouse macrophages J774A.1 (TIB67 $^{\mathrm{rm}}$, purchased from ATCC ${ }^{\mathrm{im}}$ (American Type Culture Collection (ATCC), La Jolla, California, United States) were cultivated in Dulbecco's Modified Eagle's Medium (DMEM, PAA laboratories GmbH, Colbe, Germany) containing 10\% Fetal calf serum (FCS) (Invitrogen, Carlsbad, California, United States), and $2 \mathrm{mM}$ L-glutamine (PAA laboratories $\mathrm{GmbH}$, Colbe, Germany) at $37^{\circ} \mathrm{C}$ and $5 \%$ $\mathrm{CO}_{2}$. The medium was changed twice a week.

\section{Primary microglial culture}

Cerebral cortices of newborn Sprague Dawley rats (Institute of Neuroimmunology, Bratislava, Slovakia) (1 day old) were dissected by cervical dislocation, stripped of their meninges, and mechanically dissociated by repeated pipetting followed by passing through a nylon mesh. Cells were plated in 96-well plates and $75 \mathrm{~cm}^{2}$ flasks pre-coated with poly-L-lysine $(10 \mathrm{mg} / \mathrm{ml})$ and cultivated in DMEM containing 10\% FCS and $2 \mathrm{mM}$ L-glutamine (all from Life Technologies Invitrogen, Carlsbad, California, 
United States) at $37^{\circ} \mathrm{C}, 5 \% \mathrm{CO}_{2}$ in a water-saturated atmosphere. The medium was changed twice a week. Mixed glial cultures reached confluence after 8 to 10 days in vitro. Confluent mixed glial cultures were subjected to mild trypsinization (0.05 to $0.12 \%$ ) in the presence of 0.2 to $0.5 \mathrm{mM}$ Ethylenediaminetetraacetic acid (EDTA). This resulted in the detachment of an intact layer of cells containing astrocytes, leaving undisturbed a population of firmly attached cells identified as more than 98\% microglia [40]. The cells were maintained in astrocyte-conditioned medium and were used for experiments after 24 hours in culture. The purity of microglial cell cultures isolated by this procedure was $95 \%$ (CD11b/CD18 staining).

Peripheral blood monocyte-derived macrophages (PB-MoM) Rat blood monocytes were obtained from the peripheral blood of healthy Sprague Dawley rat males (5-monthsold). Aseptically, $8 \mathrm{ml}$ of Ficoll-Paque Plus (GE Healthcare, Uppsala, Sweden) were added into a clean centrifuge tube. A total of $4 \mathrm{ml}$ of blood samples diluted with sterile PBS 1:1 were carefully layered on Ficoll-Paque Plus (GE Healthcare, Uppsala, Sweden) and centrifuged at $300 \times \mathrm{g}$ for 30 minutes at $25^{\circ} \mathrm{C}$.

Using a sterile Pasteur pipette the lymphocyte layer was transferred into a clean centrifuge tube and resuspended in PBS. The cells were centrifuged at $300 \times \mathrm{g}$ for 15 minutes at $25^{\circ} \mathrm{C}$. Isolated cells were cultivated in Roswell Park Memorial Institute (RPMI) 1640 medium containing 20\% FCS and $2 \mathrm{mM}$ L-glutamine for 2 days. Then the cells were differentiated into peripheral blood monocyte-derived macrophages (PB-MoM) with granulocyte colony-stimulating factor GM-CSF (100 ng/ml) for a further 6 days.

\section{Cell stimulation}

One day prior to the challenge of the cells with latex beads or tau oligomers, cell culture medium was replaced with serum-free DMEM medium with L-glutamine. To stimulate the cells, lipopolysaccharide (LPS) from E. coli (Sigma-Aldrich, St. Louis, Missouri, United States) was added to the medium for a final concentration of $250 \mathrm{ng} /$ $\mathrm{ml}$ for 24 hours. This concentration of LPS had minimal effect on cell viability (data not shown).

\section{Phagocytosis assay}

TIB67 macrophages and BV2 microglia cells were plated on 6-well plates at a density of $5 \times 10^{3}$ cells $/ \mathrm{cm}^{2}$. They were cultivated in the presence (stimulated) or absence (non-stimulated) of LPS and subsequently challenged either with $1 \mu \mathrm{M}$ oligomeric tau (labelled with Alexa Fluor $546)$ or with red fluorescent latex beads ( $2 \mu \mathrm{m}$, L3030, Sigma-Aldrich, St. Louis, Missouri, United States) for 2, 6 and 24 hours in DMEM medium supplemented with L-glutamine without serum. The experiments were performed in triplicate. The phagocytic activities of the cells were evaluated by in vivo cell imaging, flow cytometry and Western blot analysis.

\section{In vivo cell imaging}

Cells were plated (at a density of $5 \times 10^{3}$ cells/well) on Lab-tek chamber slides (Thermo Scientific, Rockford, Illinois, United States) pre-coated with poly-L-lysine (Sigma-Aldrich, St. Louis, Missouri, United States) and cultivated for 24 hours in DMEM medium with serum. For visualization of live cells we used MitoTracker ${ }^{\text {Ts }}$ Green FM green-fluorescent mitochondrial stain (final concentration of 200 nM, Invitrogen, Carlsbad, California, United States). Staining was done for 30 minutes under normal growth conditions. After staining the solution was replaced with fresh pre-warmed Hank's solution (SigmaAldrich, St. Louise, Missouri, United States and cells were examined by LSM 710 confocal microscope (Zeiss, Jena, Germany). At least 100 cells per chamber were analyzed for quantification, totalling ten chambers per experiment.

\section{Western blot analysis}

Cells were plated at a density of $5 \times 10^{3}$ cells $/ \mathrm{cm}^{2}$ in a 6 well plates and cultivated with $1 \mu \mathrm{M}$ oligomeric tau protein for 2, 6 and 24 hours. Before cell lysis, the cells were incubated with $0.05 \%$ trypsin for 3 minutes at $37^{\circ} \mathrm{C}$ to remove tau bound to the cell surface, the residual trypsin activity was blocked with $1 \%$ bovine serum albumin (BSA) in PBS for 30 minutes at room temperature and then the cells were harvested into lysis buffer $(200 \mathrm{mM}$ Tris, $\mathrm{pH}$ 7.4, $150 \mathrm{mM} \mathrm{NaCl}, 1 \mathrm{mM}$ EDTA, $1 \mathrm{mM} \mathrm{Na} \mathrm{VO}_{4}$, $20 \mathrm{mM} \mathrm{NaF}, 0.5 \%$ Triton X-100, $1 \times$ protease inhibitors complete EDTA-free from Roche, Mannheim, Germany). Total protein concentration of prepared cell extracts was measured by Bio-Rad protein assay (Bio-Rad laboratories $\mathrm{GmbH}$, Colbe, Germany). A total of $25 \mu \mathrm{g}$ of the proteins was separated onto $12 \%$ SDS-polyacrylamide gels and transferred to nitrocellulose membrane in 10 mM N-cyclohexyl-3-aminopropanesulfonic acid (CAPS, $\mathrm{pH}$ 11, Roth, Karlsruhe, Germany). The membranes were blocked in 5\% milk in Tris-buffered saline/Tween 20 (Sigma-Aldrich, St. Louis, Missouri, United States) (TBS-T, 137 mM NaCl, 20 mM Tris-base, pH 7.4, 0.1\% Tween 20) for 1 hour and incubated with primary antibody (DC25 antibody) overnight at $4^{\circ} \mathrm{C}$. Membranes were incubated with horseradish peroxidase (HRP)conjugated secondary antibody in TBS-T (1:3000, Dako, Glostrup, Denmark) for 1 hour at room temperature. Immunoreactive tau proteins were detected by chemiluminescence (SuperSignal West Pico Chemiluminescent Substrate, Thermo Scientific, Pittsburgh, United States) and the signals were digitized by Image Reader LAS-3000 (FUJIFILM, Bratislava, Slovakia). 


\section{Data analysis and statistics}

Each experiment was repeated at least three times. Data are presented as mean \pm standard error of the mean (SEM). Friedman's repeated measures one-way analysis of variance (ANOVA) on ranks and Dunn's method for multiple comparisons were used. Student's t-test was used for assessment of the difference between groups. Statistical significance was defined as $P<0.05$.

\section{Results}

\section{Characteristic features of tau oligomers}

A characteristic feature of most neurodegenerative disorders is the accumulation of protein aggregates and pathologically modified protein forms. In order to analyze the phagocytic activities of microglia and macrophages we used insoluble tau oligomers generated in vitro. The oligomers were prepared from recombinant truncated tau (aa 151-391 of the longest human tau isoform Tau40) tagged with fluorescent dye Alexa Fluor 546 (Invitrogen, Carlsbad, California, United States). In vitro oligomerization of the recombinant truncated tau protein was induced by polyanionic aggregation inducer heparin. The reaction was allowed to proceed overnight at $37^{\circ} \mathrm{C}$. To evaluate the progress of tau oligomerization we used thioflavin $\mathrm{T}$ fluorescence. Tau oligomerization increased in time with the highest fluorescent signal after 12 hours of incubation (Figure 1A).

We analyzed tau oligomers by Western blot analysis (detection with DC25 antibody, amino acids 347-354) and electron microscopy. Western blot showed higher molecular weights tau oligomers (45-170 kDa, Figure 1B).

Morphological examination of the oligomeric tau by transmission electron microscopy revealed the presence of small circular oligomers with diameters ranging from 10 to $30 \mathrm{~nm}$ and short filaments up to $120 \mathrm{~nm}$ long with a width of 10 to $15 \mathrm{~nm}$ (Figure 1C), similar to those described by Friedhoff et al. [41].
Immortalized TIB67 macrophages are more effective in phagocytosis of tau oligomers than BV2 microglia cell line

To evaluate the mechanism of elimination of extracellular oligomeric tau present in the brains of tauopathy patients, we analyzed phagocytic activity of BV2 mouse microglia cell line, a widely used valid model of microglial cells $[42,43]$, and monocytic/macrophage cell line J774A.1 $\left(\mathrm{ATCC}^{\mathrm{TM}} \mathrm{TIB67}^{\mathrm{TM}}\right.$ ) as a surrogate for primary macrophages [44]. Each experiment consisted of three replicates of cultures to confirm our findings. Three independent batches of cultures (BV2 and TIB67) or two or three independent isolations of either primary microglia or monocytes-derived macrophages were used (Additional file 1: Table S1).

The phagocytic study investigated four parameters: 1) phagocytic capacity (non-activated and activated) of the phagocytes against particulate matter, evaluated by standardized homogeneous particles, 2) phagocytic capacity (non-activated and activated) against abnormal oligomerized tau proteins, 3) temporal characterization of the phagocytic potency and 4) potency to degrade the internalized abnormal tau proteins. The first three parameters were analyzed using in vivo cell imaging and flow cytometry. The tau degradation activities were evaluated by Western blotting.

Phagocytic activity largely depends on the particle size. Several studies reported that maximal phagocytosis was observed for particle size with a diameter of about $2 \mu \mathrm{m}$ and that phagocytosis decreased with increasing particle size [45]. Therefore, we characterized the phagocytic capacity of microglia and macrophages with standard red fluorescent latex beads with a diameter of $2 \mu \mathrm{m}$ in activated (by LPS) and non-activated states. The process of phagocytosis was monitored by live fluorescent microscopy over the period of 24 hours at three independent time points (2, 6 and 24 hours). Individual cells were
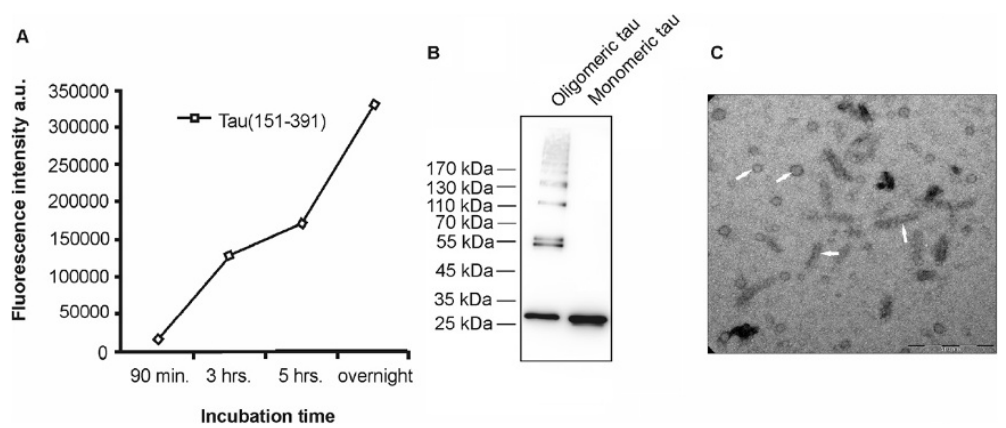

Figure 1 Characterization of tau oligomers. Oligomerized tau protein (tau151-391) was prepared by in vitro oligomerization reaction using polyanionic inducer heparin. Progress of tau oligomerization was monitored by thioflavin T fluorescence (A). Neither tau nor heparin alone in the oligomerization reaction produced significant thioflavin T fluorescence over the time course of the experiment. Monomeric tau (25 kDa, apparent molecular weight on SDS-PAGE is $30 \mathrm{kDa}$ ) and oligomerized tau (45 to $170 \mathrm{kDA}$ ) was analyzed by Western blot and visualized by monoclonal antibody DC25 (epitope 347-354 of human tau isoform Tau40) (B), which revealed multiple SDS-stable oligomeric species. Transmission electron microscopy $(\mathbf{C})$ showed tau oligomers in the form of small round particles and short filaments (arrows). Scale bar represents 200 nm. 
visualized by mitochondrial staining with MitoTracker ${ }^{\text {тM }}$ Green FM.

The activity of TIB67 in internalizing latex beads did not significantly differ over time, although it showed tendency towards increasing activity (Figure 2A, nonactivated cells/-LPS: $P=0.112$; activated cells/+LPS: $P=0.103)$. We quantified the percentage of latex beadspositive TIB67 macrophages after 2 hours (-LPS: $40 \% \pm$ $2.1 \%$ versus + LPS: $56 \% \pm 1.9 \% ; P=0.012)$, after 6 hours (-LPS: $54 \% \pm 1.4 \%$ versus + LPS: $66 \% \pm 0.7 \% ; P=0.25$ ) and after 24 hours (-LPS: $69 \% \pm 3 \%$ versus + LPS: $88 \% \pm$ $1.6 \% ; P=0.01)$. Importantly, LPS treatment increased cell phagocytic activity with statistical significance at 2 and 24 hours (Figure 2A).

Compared to TIB67 macrophages, BV2 microglia cells showed decreased potency in phagocytosis of the latex beads. No beads-positive BV2 microglia cells (stimulated with LPS or not) were observed after 2 and 6 hours. The ability of BV2 microglia to engulf latex beads significantly increased during 24 hours both under normal conditions and after stimulation with LPS (-LPS: $P=0.0046$; +LPS: $P=0.0001$ ), but even then it remained negligible in comparison to macrophages. As was the case for macrophages, statistical analysis revealed that LPS treatment significantly increased their phagocytic activity only after 24 hours (Figure 2B, +LPS: $2.6 \% \pm$ $0.3 \%$ versus - LPS: $1.3 \% \pm 0.5 \% ; P=0.0015)$.

Thus, the overall quantification showed that the ability of macrophages to phagocytose particulate matter (exemplified by the latex beads) was higher compared to BV2 cells (Figure 2C). We found that after 24 hours $69 \%$ $( \pm 0.03 \%)$ of macrophages contained engulfed latex beads, compared to only $1.3 \%( \pm 0.5 \%)$ of BV2 microglia (Figure $2 \mathrm{C}, P=0.003)$. After LPS stimulation we detected $88 \%( \pm 1.6 \%)$ beads-positive TIB67 macrophages but only $2.6 \%( \pm 0.3 \%)$ beads-positive BV2 microglia (Figure $2 \mathrm{C}, P=0.008$ ).

In order to characterize the tauopathy-relevant phagocytic activity of the two types of phagocytes, we challenged the cultivated cells with oligomerized tau. The
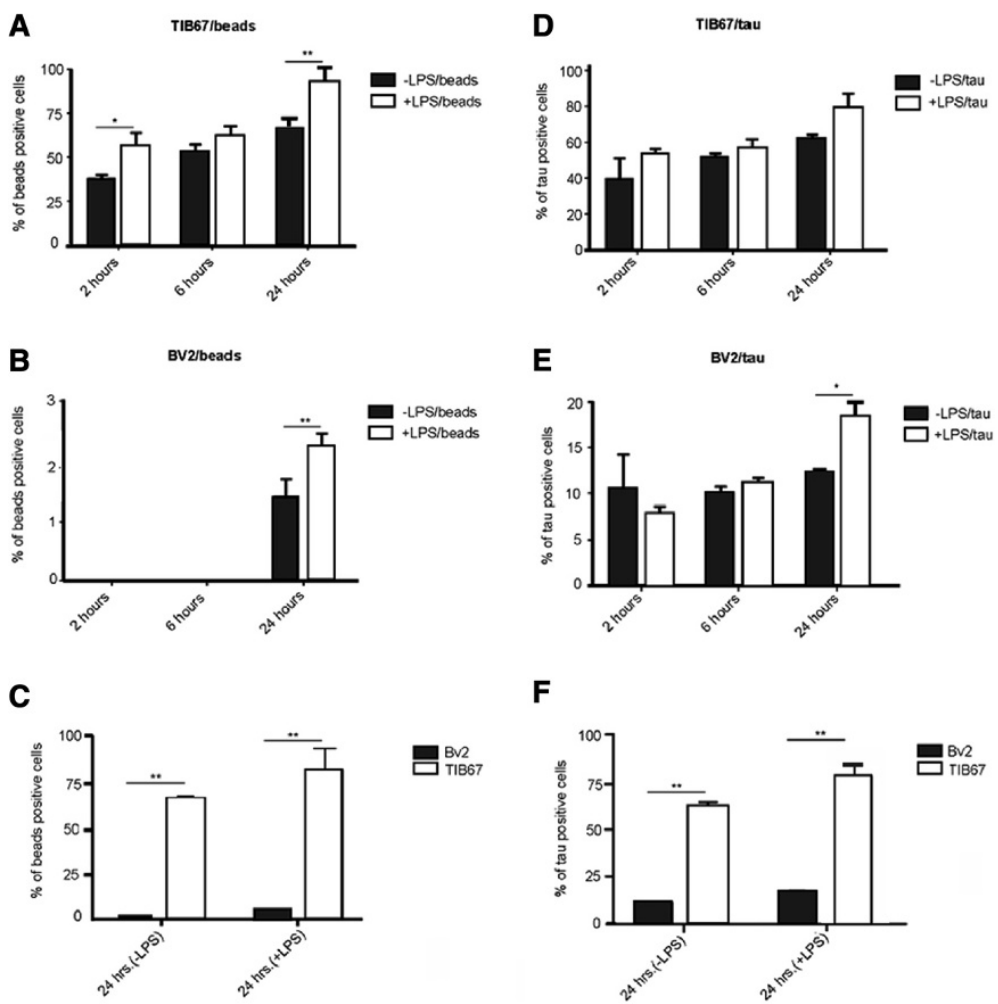

Figure 2 Comparative immunofluorescent analysis uncovered the higher potency of TIB67 macrophages phagocytose tau oligomers comparing to BV2 microglia. Live phagocytes were labelled with MitoTracker ${ }^{\mathrm{TM}}$ Green FM green-fluorescent mitochondrial stain and then challenged with red fluorescent latex beads or with oligomeric tau labelled with red Alexa Fluor 546. The panels show quantification data of TIB67 macrophages (A), BV2 microglia (B) engulfing red fluorescent beads in the presence or absence of LPS treatment. (C) Quantitative comparison of TIB67 and BV2 phagocytosis of latex beads after 24 hours. Quantification of TIB67 macrophages (D) and BV2 microglia (E) phagocytosing tau oligomers in the presence or absence of LPS treatment. (F) Quantitative comparison of TIB67 and BV2 primary microglia cell phagocytosis of tau oligomers after 24 hours. The experiments were run in triplicates. Data are presented as mean \pm standard error of the mean (SEM). Statistical significance was defined as $P<0.05\left(^{*}\right)$ or $P<0.01\left(^{* *}\right)$. Abbreviation: $P$, p-value. 
ability of TIB67 macrophages to internalize tau oligomers appeared very similar to their activity towards latex beads. The quantification of the percentage of oligomerized tau-positive macrophages showed that after 2 hours more than one third of all cells contained internalized tau oligomers (Figure 2D, 39\% $\pm 2.3 \%$ ), which increased over time to almost two thirds after 24 hours (Figure 2D, 6 hours: $51 \% \pm 1.1 \%$; 24 hours: $62 \% \pm 3.1 \%$ ). LPS-stimulated macrophages exhibited increased (albeit not significantly) phagocytic activity at all time points (Figure 2D, 2 hours: $54 \% \pm 1.9 \%$, - LPS versus + LPS $P=0.47 ; \quad 6$ hours: $60.3 \% \pm 1.9 \%, \quad-$ LPS versus + LPS $P=0.18$; 24 hours: $79 \% \pm 2.7 \%$, - LPS versus + LPS $P=0.18$ ). The ability of TIB67 macrophages to phagocytose tau oligomers significantly increased over time only after LPS treatment (Figure 2D, +LPS: $P=0.044$; -LPS: $P=0.2$ ). It is important to note that LPS stimulation had a rather minor effect on the phagocytosis of tau oligomers by macrophages.

Analysis of phagocytic activity of BV2 microglia revealed that less than $15 \%$ of all cells were able to internalize tau oligomers at any time point (Figure 2E, -LPS). LPS stimulation did not increase this phagocytic activity during the first 6 hours (2 hours: -LPS 10.3\% $\pm 0.8 \%$, +LPS $8.7 \% \pm$ $0.09 \%, \quad P=0.45 ; 6$ hours: - LPS $10.2 \% \pm 0.5 \%$, +LPS $11.4 \% \pm 0.3 \%, P=0.36$ ) and only slightly after 24 hours (-LPS: $11.6 \% \pm 0.6 \%$; +LPS: $17.4 \% \pm 0.3 \%, \quad P=0.011$ ). This LPS-stimulated phagocytic activity significantly increased with time $(P=0.021)$.

Our comparative study revealed that the number of oligomerized tau-positive TIB67 macrophages was more than five times higher than the number of tau positive BV2 microglia cells (Figure 2F, $62 \% \pm 3.1 \%$ versus $11.2 \% \pm$ $0.6 \%$; $P=0.003)$. Similar results were obtained after LPS stimulation (Figure 2F, $78.7 \% \pm 2.7 \%$ versus $15.4 \% \pm 0.3 \%$, $P=0.004)$.

We used the z-stacking function of the laser scanning confocal microscope to confirm that the tau oligomers are indeed internalized and not just attached to the outside of the cells (Figure 3). Confocal images of the phagocytes after 24 hours of incubation with tau oligomers showed that oligomerized tau (red) is localized within the cell bodies (green) of TIB67 macrophages (Figure 3A - without LPS stimulation, Figure 3B - with LPS stimulation). In the case of non-stimulated BV2 microglia, there is a smaller amount of tau oligomers associated with the cells and it seems rather attached to the outside of the cells (Figure 3C). On the other hand, LPS-stimulated microglia contain larger amounts of tau within the cells, although the amount is still smaller than that found in macrophages (Figure 3D). These observations support data coming from our quantitative study where we found that BV2 microglia are less potent in phagocytosing tau oligomers than TIB67 macrophages.
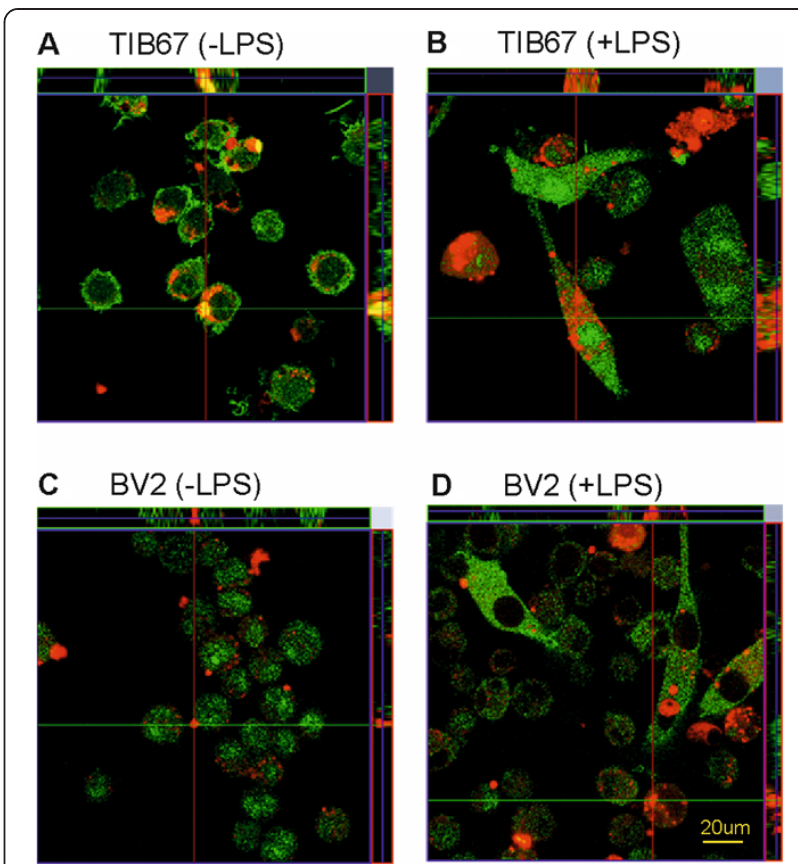

Figure 3 Confocal imaging showing that TIB67 macrophages are more efficient in phagocytosis of tau oligomers than BV2 microglia. Confocal cross-section analyses of cells show a higher number of tau oligomers engulfed by macrophages than by BV2 microglial cells. Micrographs show tau oligomers positive TIB67 macrophages non-treated (A) or treated with LPS (B). Cross-sections show that tau is internalized within the cells. Tau oligomer positive BV2 cells without and with LPS stimulation are shown in panels (C) and (D), respectively. LPS-stimulated microglia contain tau oligomers internalized, while non-stimulated cells have tau particles rather attached to the outside of the cells. Scale bar: $20 \mu \mathrm{m}$. Abbreviation: $\mu \mathrm{m}$, micrometer.

Peripheral rat blood monocyte-derived macrophages are more effective in phagocytosis of tau oligomers than rat primary microglia

In order to show that our analysis is relevant to an in vivo situation, we tested the phagocytic activity of primary microglial cells and peripheral rat blood monocyte-derived macrophages (PB-MoM) as well.

The activity of $\mathrm{PB}-\mathrm{MoM}$ in internalizing latex beads increased over time (Figure 4A, non-activated cells/LPS: $P=0.0015$; activated cells/+LPS: $P=0.0019)$. We quantified the percentage of latex beads-positive $\mathrm{PB}$ MoM after 2 hours (-LPS: $15 \% \pm 1.2 \%$ versus + LPS: $25 \% \pm 1 \% ; P=0.052$ ), after 6 hours (-LPS: $51 \% \pm 1.4 \%$ versus + LPS: $68 \% \pm 1 \% ; P=0.23)$ and after 24 hours (-LPS: $100 \% \pm 0.3 \%$ versus + LPS: $100 \% \pm 0.6 \%)$. Importantly, LPS treatment did not increase the cell phagocytic activity over time.

The potency of primary microglia to engulf latex beads increased during 24 hours both under normal conditions and after stimulation with LPS (Figure 4B, -LPS: $P=0.0002$; + LPS: $P=0.001)$. After 24 hours, the phagocytic 

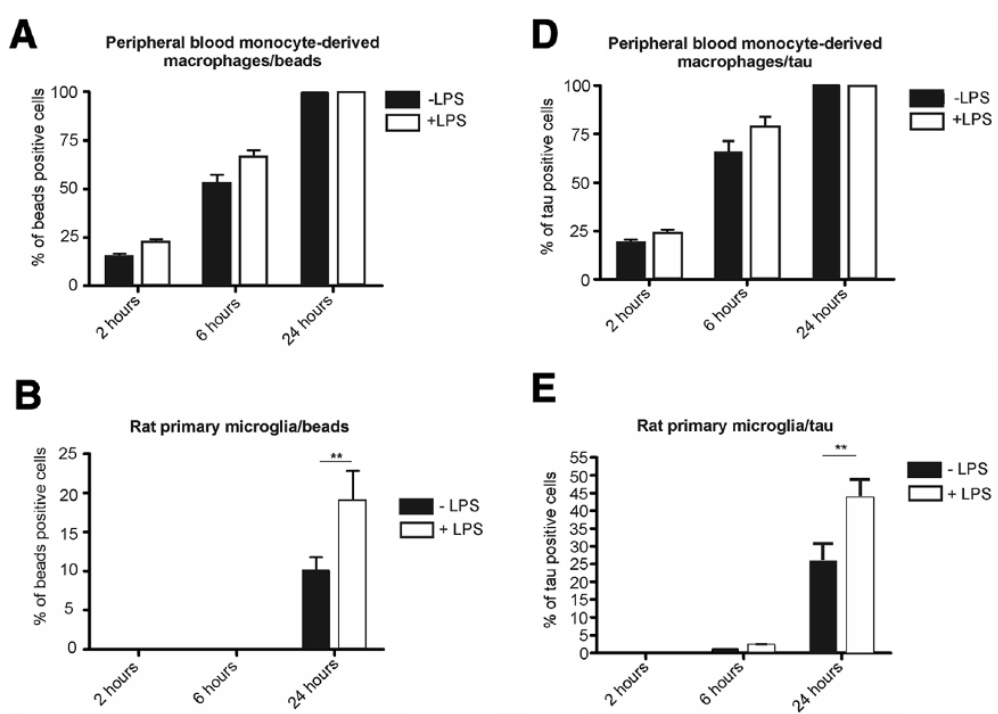

E

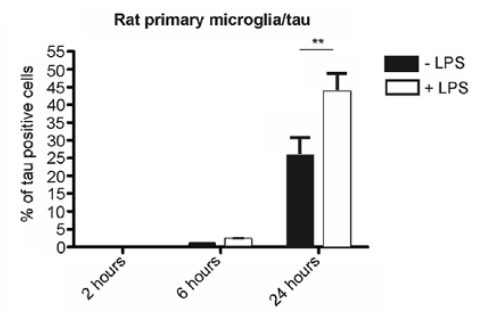

$\mathbf{F}$
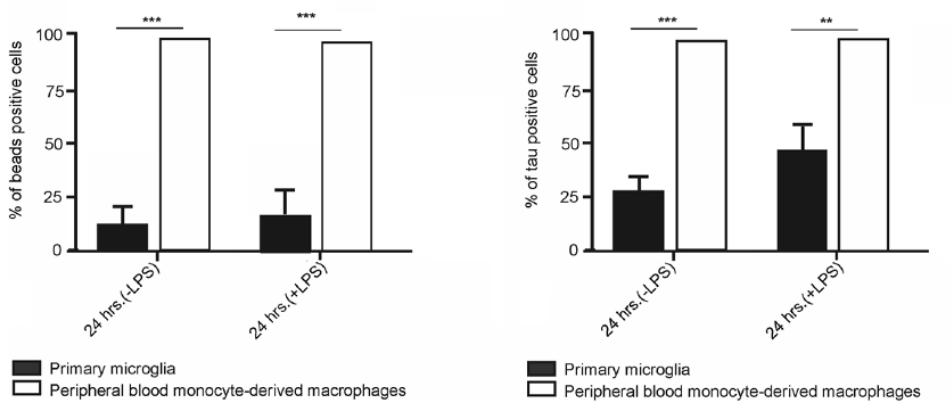

Figure 4 Immunofluorescent study reveals a higher efficacy of peripheral blood-derived monocytes to phagocytose tau oligomers than primary microglia. The panels show quantification data of PB-MoM macrophages (A) and primary microglia (B) engulfing oligomerized beads in the presence or absence of LPS treatment. (C) Quantitative comparison of PB-MoM macrophages and primary microglia phagocytic efficacy of beads oligomers after 24 hours. Quantification of PB-MoM macrophages (D) and primary microglia (E) phagocytosing tau oligomers in the presence or absence of LPS treatment. (F) Quantitative comparison of PB-MoM macrophages and primary microglia and primary microglia cells phagocytosis of tau oligomers after 24 hours. The experiments were run in triplicates. Data are presented as mean \pm standard error of the mean (SEM). Statistical significance was defined as $P<0.05\left(^{*}\right)$ or $\left.P<0.01{ }^{* *}\right)$. Abbreviations: SEM, standard error of the mean; $P, p-v a l u e ; P B-M o M$, Peripheral blood monocyte-derived macrophages.

activity of primary microglia did not reach the activity of peripheral macrophages (Figure 4B, -LPS: $10.8 \% \pm 0.6 \%$ versus + LPS: $19.3 \% \pm 1 \%$ ). Strikingly, LPS treatment significantly increased the cell phagocytic activity after 24 hours $(P=0.0035)$.

We found that after 24 hours, $100 \%$ of peripheral rat blood monocyte-derived macrophages contained engulfed latex beads, while only $10.8 \%( \pm 0.5 \%)$ of primary microglia showed such inclusions (Figure 4C, $P=0.001$ ). After LPS stimulation we detected $100 \%$ beads-positive macrophages, but only $19.3 \%$ beads-positive primary microglia (Figure $4 \mathrm{C}, P=0.0012$ ).

The analysis of the phagocytosis of tau oligomers by peripheral rat blood monocyte-derived macrophages and primary microglia revealed interesting differences.
PB-MoM exhibited an extremely high ability to phagocytose oligomerized tau. The quantification of the percentage of oligomerized tau-positive PB-MoM increased over time (Figure 4D, 2 hours: 19\% $\pm 1.3 \%$; 6 hours: $69 \% \pm 2.1 \%$; 24 hours: $100 \% \pm 0.1 \% ; P=0.011)$. LPS-stimulated macrophages exhibited increased (but not significantly) phagocytic activity at all time points (Figure 4D, 2 hours: $24 \% \pm$ $0.9 \%$; 6 hours: $77.3 \% \pm 1.8 \%$; 24 hours: $100 \% \pm 0.7 \%$ ). Similarly to TIB67 cells, LPS stimulation had no effect on phagocytosis of tau oligomers by peripheral rat blood monocyte-derived macrophages.

Primary microglial cells displayed limited phagocytic activity during the 6-hour incubation time, even after LPS stimulation (Figure 2E, 2 hours: - LPS $0.3 \% \pm 0.08 \%$, +LPS $0.42 \% \pm 0.009 \%, P=0.65 ; 6$ hours: - LPS $1.8 \% \pm 0.05 \%$, + LPS 
$2.4 \% \pm 0.03 \%, P=0.36)$. The activity increased after LPS stimulation only after 24 hours (-LPS: $26.4 \% \pm 0.3 \%,+$ LPS: $42.6 \% \pm 0.6 \%, P=0.01)$.

Thus, the overall quantification showed that the ability of peripheral rat blood monocyte-derived macrophages to phagocytose oligomerized tau was higher compared to primary microglia (Figure 4F). We found that after 24 hours $100 \%$ of PB-MoM macrophages contained engulfed oligomerized tau, compared to only $26.4 \%$ of primary microglia (Figure 2F, $P=0.001$ ). After LPS stimulation we detected $100 \%$ tau positive PB-MoM macrophages and $42.6 \%$ tau-positive primary microglia cells (Figure 4F, $P=0.0014$ ).

Our comparative study revealed that the number of oligomerized tau-positive PB-MoM macrophages was almost four times higher than the number of tau positive primary microglia cells in the absence of LPS, and two times higher after stimulation with LPS.

A confocal study revealed that PB-MoM are very effective in phagocytosis of tau oligomers regardless of LPS treatment (Figure 5A,B). In the case of non-stimulated primary microglia cells, there is a smaller amount of tau oligomers associated with the cells (Figure 5C), while LPS-stimulated microglia seems to be more effective in phagocytosis of tau oligomers than non-treated microglia (Figure 5D).

Western blot analysis revealed that LPS stimulation increased degradation of tau oligomers by macrophages and microglia In order to evaluate the ability of macrophages to degrade phagocytosed tau oligomers we analyzed the presence of internalized tau by Western blot analysis. For total tau staining we used phosphorylation independent antibody DC25. The Western blot showed a decrease of oligomeric tau with time in the cell lysates from macrophages and microglia (Figure 6A,B,C,D, lane '2 hours' compared to ' 6 hours' and ' 24 hours'). Interestingly, TIB67 macrophage cells can phagocytose oligomeric tau regardless of LPS treatment, however the efficacy is higher after LPS stimulation (Figure 6A). Neither BV2 microglia nor primary microglia are able to degrade tau oligomers without LPS treatment (Figure 6B,D).

\section{Discussion}

Alzheimer's disease (AD) is a widespread progressive neurodegenerative disorder characterized by the presence of neurofibrillary tangles consisting of hyperphosphorylated and truncated tau proteins and extracellular senile plaques composed of amyloid- $\beta$ [46-51]. Previous studies have indicated that neuroinflammation significantly modulates the pathogenesis of $\mathrm{AD}$ by increased activation of brain immune cells and their potency to phagocytose and enzymatically degrade pathologic lesions [52-54].

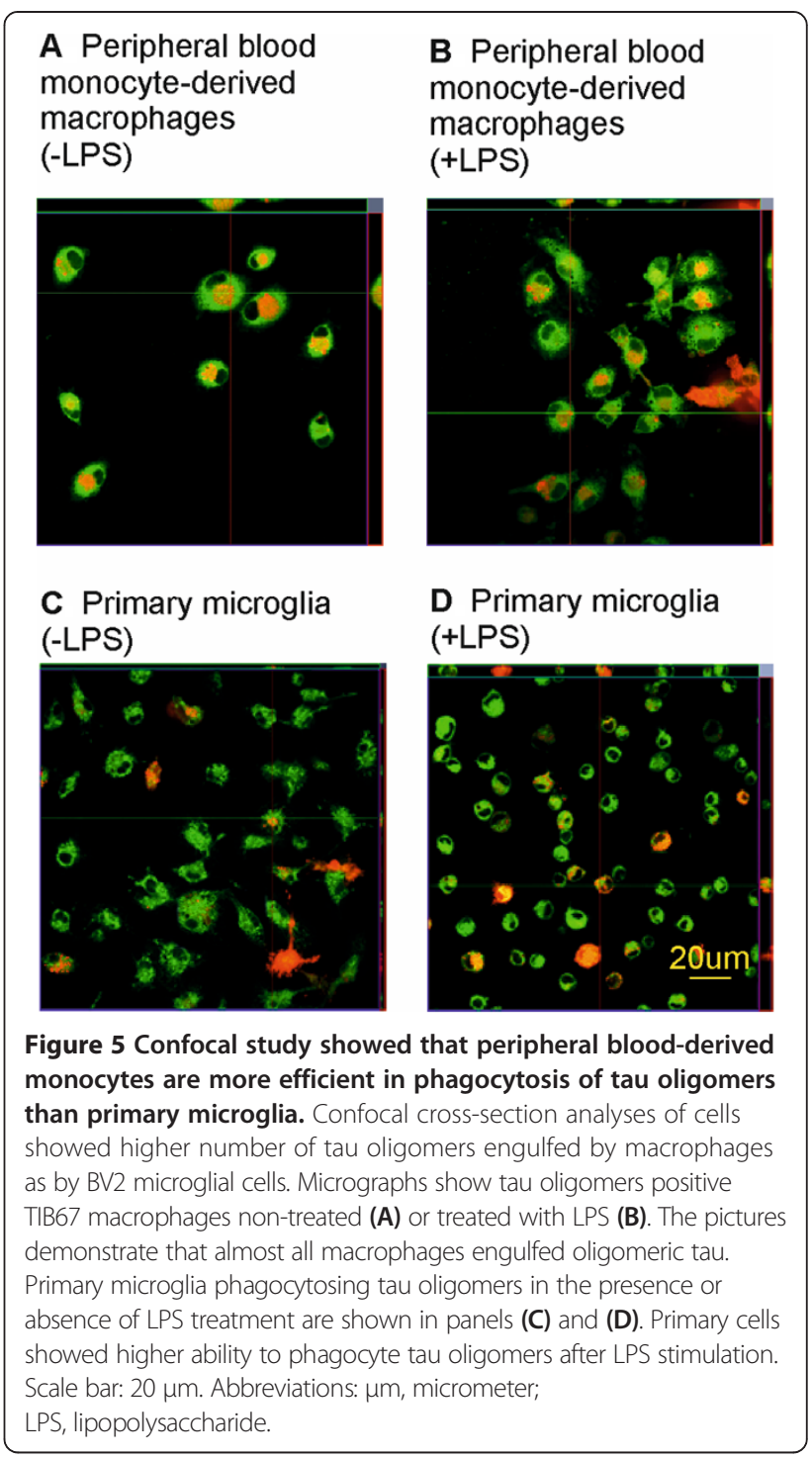

In early stages of $\mathrm{AD}$, microglia activation becomes protective and delays the disease progression by effective clearance of pathological lesions [55-57], while in the later stages, microglia lose their protective function and release pro-inflammatory cytokines such as tumor necrosis factoralpha (TNF- $\alpha$ ) and interleukin-1beta (IL-1 $\beta$ ) [4,5,58-60]. It was shown that microglia cells isolated from the aged brains exhibit increased release of cytokines as compared to those from the young brains, suggesting an elevated inflammatory state in aged microglia [61].

The issue of whether microglia are able to eliminate pathological lesions such as neurofibrillary tangles or senile plaques from $\mathrm{AD}$ brain still remains the matter of controversy. Wisniewski et al. [6] observed that human brain-resident microglia cells appeared in the close proximity of amyloid plaques but they did not contain $\beta$-amyloid fibrils in their lysosomal compartment. In 


\section{A TIB67}

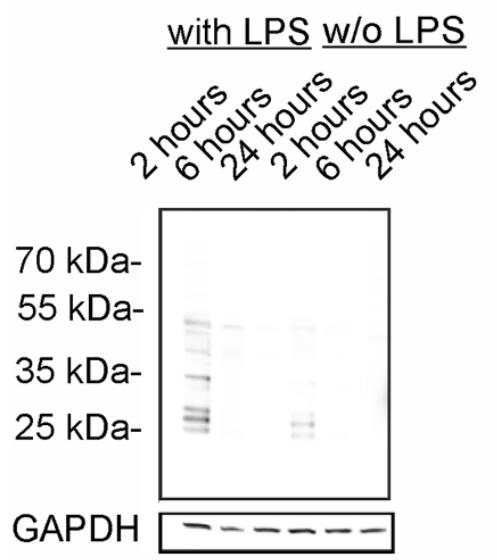

\section{Peripheral blood monocyte-derived macrophages}

\section{B BV2}

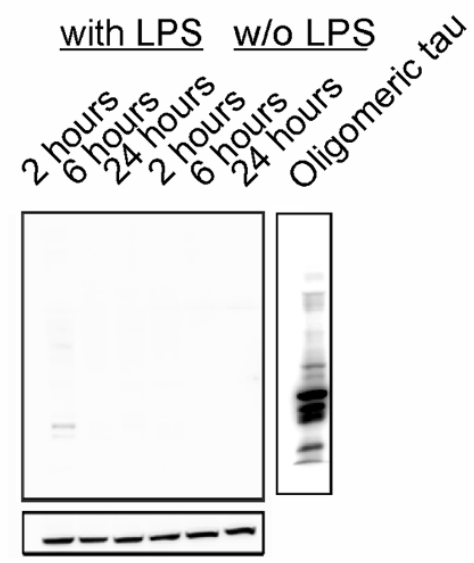

D Primary microglia

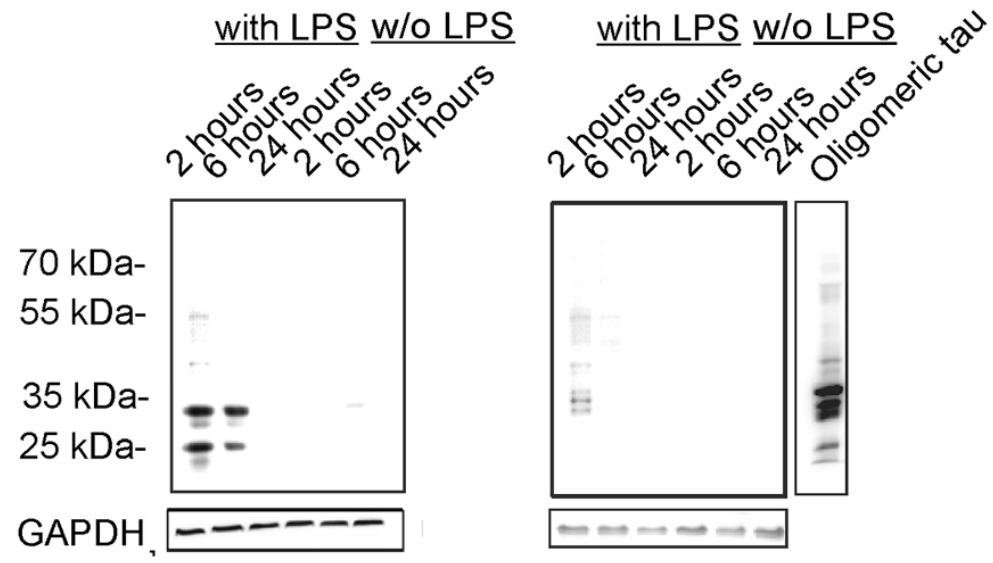

Figure 6 Macrophages and microglia can degrade tau oligomers. Western blot analyses of extracts from TIB67 macrophages (A), BV2 microglia (B), peripheral blood monocyte-derived macrophages (C) and primary microglia (D) challenged with oligomerized (misfolded) tau for 2, 6 and 24 hours showed that macrophages are more potent in degradation of tau oligomers than microglia. Microglia were able to phagocytose and degrade tau oligomers only after LPS stimulation. Western blots were developed with DC25 antibody. W/o, without. Abbreviations: w/o, without; LPS, lipopolysaccharide.

contrast to this finding, some authors demonstrated that human microglia cells obtained from AD brains could engulf $A \beta[52,62]$, however they could not degrade fibrillar A $\beta[8,63]$. Microglia with a defective lysosomal enzymatic complex have weak acidic lysosomes, which would decrease the activity of many proteases and could lead to the inability to degrade $A \beta$ effectively [64]. On the other hand, it has been suggested that the acidic conditions in microglial endosomes and lysosomes can promote assembly or growth of fibrillar $A \beta$ plaques, which could then be released from the cells into the extracellular space [65-67].
It was shown that tau oligomers were significantly elevated in the $\mathrm{AD}$ brain, preceded the tangle formation and had contributed to the progression of tau neurodegeneration $[31,32]$. In our study, we used recombinant truncated tau (aa 151-391/4R) derived from AD brains [37] to prepare tau oligomers. In order to analyze phagocytic activity of microglia we used immortalized mouse microglia cell line BV2 and primary microglial cells. Several research papers have demonstrated that BV2 cells can be used as alternative model system for primary microglia cultures for experiments examining brain inflammation, and faithfully 
mimic behaviors of primary microglia cells [68], as well as exhibit a robust phagocytic response [69-71]. Our results show that neither primary microglial cells nor BV2 microglia were able to effectively phagocytose oligomeric tau when compared with macrophages. However, after activation with LPS, the phagocytic activity of both primary microglial cells and BV2 cells increased. Previously, Cooper et al. [72] found that LPS could increase the phagocytic activity of microglia via increased Fc receptor capacity. Further, phagocytosis-related events, such as enhanced hexose monophosphate shunt activity, $\mathrm{H}_{2} \mathrm{O}_{2}$ formation and nitroblue tetrazolium reduction could also be stimulated by LPS [72]. We can hypothesize that LPS stimulation can activate molecular pathways involved in phagocytosis of tau oligomers.

Our Western blot analyses showed that LPS can stimulate degradation of oligomeric tau. Treatment with inflammatory agents such as LPS probably acidifies microglial lysosomes and thus increases degradation of oligomerized tau protein. It has been shown that stimulation by LPS increased the expression of CD68 that is responsible for lysosomal activity [73]. This indicates that acute inflammation can improve the microglial ability to phagocytose oligomeric tau.

The question of whether blood-borne leukocytes can penetrate into the $\mathrm{AD}$ brain yielded contradictory results. Some authors proposed that the chronic inflammatory response implicated in $\mathrm{AD}$ was provided almost exclusively by resident CNS cells without any apparent influx of leukocytes from the blood [3,74]. Others have demonstrated that hematopoietic cells can enter the AD brain [75-78] or rodent model brain $[26,79,80]$. Some animal studies using bone marrow transplant with green fluorescent proteinexpressing myeloid cells suggest that monocytes are recruited to the brain parenchyma, where they evolve morphologically and functionally into microglia [81]. It was also shown that no brain resident microglia cells but circulating peripheral monocytes could be responsible for the phagocytosis and degradation of senile plaques in rat and human brain [81]. Fiala et al. [82] also showed that peripheral macrophages are highly capable of phagocytosing synthetic $A \beta$ peptides. On the other hand, the presence of $\beta$-amyloid fibrils was observed in lysosomes of peripheral macrophages that infiltrated the brains of $\mathrm{AD}$ patients after stroke.

Here we show that macrophages are more effective in the phagocytosis of tau oligomers, the main component of neurofibrillary tangles in $\mathrm{AD}$, than microglial cells. Our finding that macrophages succeed in the degradation of tau oligomers has provided insight into the possibility of utilizing them for targeted cell therapy for AD.

\section{Conclusions}

Our data suggests that similar to the case with $A \beta$, microglia are not efficient enough to remove extracellular oligomeric tau. However we can conclude that macrophages display potential in the elimination of oligomeric tau from the AD brain.

\section{Additional file}

Additional file 1: Table S1. Raw data used for statistical analysis.

\section{Abbreviations}

Aa: Amino acids; AB: Amyloid-beta; AD: Alzheimer disease; BBB: Blood-brain barrier; CNS: Central nervous system; IL-1ß: Interleukin-1beta; LPS: Lipopolysaccharide; MHC-II: Major histocompatibility complex class II; NFT: Neurofibrillary tangle; ThT: Thioflavin T; TNF-a: Tumor necrosis factor-alpha; SEM: standard error of the mean; P: p-value; w/o: without; um: micrometer; PB-MoM: Peripheral blood monocyte-derived macrophages.

\section{Competing interests}

The authors declare that they have no competing interests.

\section{Authors' contributions}

All data was collected, analyzed and interpreted by PM and MZ. AK developed the method for tau oligomerization and participated in conceiving and designing of the study. ZK and KP carried out the immunocytochemical staining and confocal study. NZ was the leading, coordinating and decisive mind of the project and shaped the final form of the manuscript. MN, BK and NZ drafted the manuscript. All authors read and approved the final manuscript.

\section{Acknowledgements}

This work was supported by Axon Neuroscience and research grants APW 0200-11, 0206-11, 0399-10 and structural fund 26240220046.

Received: 2 May 2014 Accepted: 25 August 2014

Published online: 13 September 2014

\section{References}

1. Akiyama H, Barger S, Barnum S, Bradt B, Bauer J, Cole GM, Cooper NR, Eikelenboom P, Emmerling M, Fiebich BL, Finch CE, Frautschy S, Griffin WS, Hampel H, Hull M, Landreth G, Lue L, Mrak R, Mackenzie IR, McGeer PL, O'Banion MK, Pachter J, Pasinetti G, Plata-Salaman C, Rogers J, Rydel R, Shen Y, Streit W, Strohmeyer R, Tooyoma I, et al: Inflammation and Alzheimer's disease. Neurobiol Aging 2000, 21(Suppl 3):383-421.

2. Walsch S, Aisen P: Inflammatory processes in Alzheimer's disease. Expert Rev Neurotherapeutics 2004, 4:793-798.

3. Eikelenboom P, Veerhuis R, Scheper W, Rozemuller AJM, van Gool W, Hoozemans J: The significance of neuroinflammation in understanding Alzheimer's disease. J Neural Transm 2006, 113:1685-1695.

4. Meda L, Cassatella MA, Szendrei Gl, Otvos L Jr, Baron P, Villalba M, Ferrari D, Rossi F: Activation of microglial cells by beta-amyloid protein and interferon-gamma. Nature 1995, 374:647-650.

5. Tan J, Town T, Paris D, Mori T, Suo Z, Crawford F, Mattson MP, Flavell RA, Mullan M: Microglial activation resulting from CD40-CD40L interaction after b-amyloid stimulation. Science 1999, 286:2352-2355.

6. Wisniewski HM, Wegiel J, Wang KC, Kujawa M, Lach B: Ultrastructural studies of the cells forming amyloid fibers in classical plaques. Can J Neurol Sci 1989, 16(Suppl 4):535-542.

7. Frackowiak J, Wisniewski HM, Wegiel J, Merz GS, lqbal K, Wang KC: Ultrastructure of the microglia that phagocytose amyloid and the microglia that produce beta-amyloid fibrils. Acta Neuropathol 1992, 84:225-233.

8. Chung H, Brazil MI, Soe TT, Maxfield FR: Uptake, degradation, and release of fibrillar and soluble forms of Alzheimer's amyloid beta-peptide by microglial cells. J Biol Chem 1999, 274(Suppl 45):32301-32308.

9. Malm T, Koistinaho M, Muona A, Magga J, Koistinaho J: The role and therapeutic potential of monocytic cells in Alzheimer's disease. Glia 2010, 58(Suppl 8):889-900 
10. Simard AR, Soulet $D$, Gowing G, Julien JP, Rivest S: Bone marrow-derived microglia play a critical role in restricting senile plaque formation in Alzheimer's disease. Neuron 2006, 49:489-502

11. Fiala M, Lin J, Ringman J, Kermani-Arab V, Tsao G, Patel A, Lossinsky AS, Graves MC, Gustavson A, Sayre J, Sofroni E, Suarez T, Chiappelli F, Bernard G: Ineffective phagocytosis of amyloid-beta by macrophages of Alzheimer's disease patients. J Alzheimers Dis 2005, 7:221-232.

12. Cras $P$, Kawai M, Siedlak S, Perry G: Microglia are associated with the extracellular neurofibrillary tangles of Alzheimer disease. Brain Res 1991, 558:312-314.

13. DiPatre PL, Gelman BB: Microglial cell activation in aging and Alzheimer disease: partial linkage with neurofibrillary tangle burden in the hippocampus. J Neuropathol Exp Neurol 1997, 56:143-149.

14. Sheng JG, Mrak RE, Griffin WS: Glial-neuronal interactions in Alzheimer disease: progressive association of IL-1alpha + microglia and S100beta + astrocytes with neurofibrillary tangle stages. J Neuropathol Exp Neurol 1997, 56(Suppl 3):285-290.

15. Overmyer M, Helisalmi S, Soininen H, Laakso M, Riekkinen $P$, Alafuzoff I: Reactive microglia in aging and dementia: an immunohistochemical study of postmortem human brain tissue. Acta Neuropathol 1999, 97:383-392.

16. Sheffield LG, Marquis JG, Berman NE: Regional distribution of cortical microglia parallels that of neurofibrillary tangles in Alzheimer's disease. Neurosci Lett 2000, 285:165-168.

17. Paulus W, Bancher $C$, Jellinger K: Microglial reaction in Pick's disease. Neurosci Lett 1993, 161(Suppl 1):89-92.

18. Schwab C, Steele JC, McGeer PL: Neurofibrillary tangles of Guam parkinson-dementia are associated with reactive microglia and complement proteins. Brain Res 1996, 707:196-205.

19. Ishizawa K, Dickson DW: Microglial activation parallels system degeneration in progressive supranuclear palsy and corticobasal degeneration. I Neuropathol Exp Neurol 2001, 60:647-657.

20. Gerhard A, Watts J, Trender-Gerhard I, Turkheimer F, Banati RB, Bhatia K, Brooks DJ: In vivo imaging of microglial activation with [11C](R)-PK11195 PET in corticobasal degeneration. Mov Disord 2004, 19(Suppl 10):1221-1226.

21. Henkel K, Karitzky J, Schmid M, Mader I, Glatting G, Unger JW, Neumaier B, Ludolph AC, Reske SN, Landwehrmeyer GB: Imaging of activated microglia with PET and [11C]PK 11195 in corticobasal degeneration. Mov Disord 2004, 19(Suppl 7):817-821.

22. Bellucci A, Westwood AJ, Ingram E, Casamenti F, Goedert M, Spillantini MG Induction of inflammatory mediators and microglial activation in mice transgenic for mutant human P301S tau protein. Am J Pathol 2004, 165:1643-1652.

23. Ikeda M, Shoji M, Kawarai T, Kawarabayashi T, Matsubara E, Murakami T, Sasaki A, Tomidokoro Y, Ikarashi Y, Kuribara H, Ishiguro K, Hasegawa M, Yen SH, Chishti MA, Harigaya Y, Abe K, Okamoto K, St George-Hyslop P, Westaway D: Accumulation of filamentous tau in the cerebral cortex of human tau R406W transgenic mice. Am J Pathol 2005, 166:521-531.

24. Yoshiyama Y, Higuchi M, Zhang B, Huang SM, Iwata N, Saido TC, Maeda J, Suhara T, Trojanowski JQ, Lee VM: Synapse loss and microglial activation precede tangles in a P301S tauopathy mouse model. Neuron 2007, 53:337-351.

25. Sasaki A, Kawarabayashi T, Murakami T, Matsubara E, Ikeda M, Hagiwara H, Westaway D, George-Hyslop PS, Shoji M, Nakazato Y: Microglial activation in brain lesions with tau deposits: comparison of human tauopathies and tau transgenic mice TgTauP301L. Brain Res 2008, 1214:159-168.

26. Zilka N, Stozicka Z, Kovac A, Pilipcinec E, Bugos O, Novak M: Human misfolded truncated tau protein promotes activation of microglia and leukocyte infiltration in the transgenic rat model of tauopathy. J Neuroimmuno/ 2009, 209:16-25.

27. Stozicka Z, Zilka N, Novak P, Kovacech B, Bugos O, Novak M: Genetic background modifies neurodegeneration and neuroinflammation driven by misfolded human tau protein in rat model of tauopathy: implication for immunomodulatory approach to Alzheimer's disease. J Neuroinflammation 2010, 7:64

28. Kovac A, Zilka N, Kazmerova Z, Cente M, Zilkova M, Novak M: Misfolded truncated protein $\tau$ induces innate immune response via MAPK pathway. J Immunol 2011, 187(Suppl 5):2732-2739.

29. Zilka N, Kazmerova Z, Jadhav S, Neradil P, Madari A, Obetkova D, Bugos O, Novak M: Who fans the flames of Alzheimer's disease brains? Misfolded tau on the crossroad of neurodegenerative and inflammatory pathways. J Neuroinflammation 2012, 9:47.
30. Asai H, Ikezu S, Woodbury ME, Yonemoto GM, Cui L, Ikezu T: Accelerated neurodegeneration and neuroinflammation in transgenic mice expressing P301L tau mutant and tau-tubulin kinase 1. Am J Pathol 2014, 184(Suppl 3):808-818.

31. Maeda S, Sahara N, Saito Y, Murayama S, Ikai A, Takashima A: Increased levels of granular tau oligomers: an early sign of brain aging and Alzheimer's disease. Neurosci Res 2006, 54(Suppl 3):197-201.

32. Maeda S, Sahara N, Saito Y, Murayama M, Yoshiike Y, Kim H, Miyasaka T, Murayama S, Ikai A, Takashima A: Granular tau oligomers as intermediates of tau filaments. Biochemistry 2007, 46(Suppl 12):3856-3861.

33. Lasagna-Reeves CA, Castillo-Carranza DL, Sengupta U, Guerrero-Munoz MJ, Kiritoshi T, Neugebauer V, Jackson GR, Kayed R: Alzheimer brain-derived tau oligomers propagate pathology from endogenous tau. Sci Rep 2012, 2:700.

34. Novak M, Jakes R, Edwards PC, Milstein C, Wischik CM: Difference between the tau protein of Alzheimer paired helical filament core and normal tau revealed by epitope analysis of monoclonal antibodies 423 and 7.51 . Proc Natl Acad Sci U S A 1991, 88:5837-5841.

35. Novak M, Kabat J, Wischik CM: Molecular characterization of the minimal protease resistant tau unit of the Alzheimer's disease paired helical filament. EMBO J 1993, 12:365-370.

36. Vechterova L, Kontsekova E, Zilka N, Ferencik M, Ravid R, Novak M: DC11: a novel monoclonal antibody revealing Alzheimer's disease-specific tau epitope. Neuroreport 2003, 14:87-91.

37. Zilka N, Filipcik P, Koson P, Fialova L, Skrabana R, Zilkova M, Rolkova G, Kontsekova E, Novak M: Truncated tau from sporadic Alzheimer's disease suffices to drive neurofibrillary degeneration in vivo. FEBS Lett 2006, 580:3582-3588.

38. Koson P, Zilka N, Kovac A, Kovacech B, Korenova M, Filipcik P, Novak M: Truncated tau expression levels determine life span of a rat model of tauopathy without causing neuronal loss or correlating with terminal neurofibrillary tangle load. Eur J Neurosci 2008, 28:239-246.

39. Csokova N, Skrabana R, Liebig HD, Mederlyova A, Kontsek P, Novak M: Rapid purification of truncated tau proteins: model approach to purification of functionally active fragments of disordered proteins, implication for neurodegenerative diseases. Protein Expr Purif 2004 35:366-372.

40. Saura J, Petegnief V, Wu X, Liang Y, Paul SM: Microglial apolipoprotein E and astroglial apolipoprotein J expression in vitro: opposite effects of lipopolysaccharide. J Neurochem 2003, 85:1455-1467.

41. Friedhoff $P$, Schneider A, Mandelkow EM, Mandelkow E: Rapid assembly of Alzheimer-like paired helical filaments from microtubule-associated protein tau monitored by fluorescence in solution. Biochemistry 1998 , 37:10223-10230.

42. Henn A, Lund S, Hedtjarn M, Schrattenholz A, Porzgen P, Leist M: The suitability of BV2 cells as alternative model system for primary microglia cultures or for animal experiments examining brain inflammation. ALTEX 2009, 26:83-94.

43. Gresa-Arribas N, Vieitez C, Dentesano G, Serratosa J, Saura J, Sola C: Modelling neuroinflammation in vitro: a tool to test the potential neuroprotective effect of anti-inflammatory agents. PLOS One 2012, 7:45227.

44. Kang J, Park KH, Kim JJ, Jo EK, Han MK, Kim UH: The role of CD38 in Fcgamma receptor (FcgammaR)-mediated phagocytosis in murine macrophages. J Biol Chem 2012, 287:14502-14514.

45. Champion JA, Walker A, Mitragotri S: Role of particle size in phagocytosis of polymeric microspheres. Pharm Res 2008, 25:1815-1821.

46. Glenner GG, Wong CW: Alzheimer's disease: initial report of the purification and characterization of a novel cerebrovascular amyloid protein. Biochem Biophys Res Commun 1984, 120(Suppl 3):885-890.

47. Masters CL, Simms G, Weinman NA, Multhaup G, McDonald BL, Beyreuther K: Amyloid plaque core protein in Alzheimer disease and Down syndrome. Proc Natl Acad Sci U S A 1985, 82:4245-4249.

48. Wischik CM, Novak M, Thogersen HC, Edwards PC, Runswick MJ, Jakes R, Walker JE, Milstein C, Roth M, Klug A: Isolation of a fragment of tau derived from the corof the paired helical filament of Alzheimer disease. Proc Natl Acad Sci U S A 1988, 85:4506-4510.

49. Braak H, Braak E: Neuropathological stageing of Alzheimer-related changes. Acta Neuropathol (Berl) 1991, 82:239-259.

50. Novak M: Truncated tau protein as a new marker for Alzheimer's disease. Acta Virol 1994, 38(Suppl 3):173-189.

51. Iqbal K, Liu F, Gong CX, Grundke-lqbal I: Tau in Alzheimer disease and related tauopathies. Curr Alzheimer Res 2010, 7(Suppl 8):656-664. 
52. Rogers J, Lue LF: Microglial chemotaxis, activation and phagocytosis of amyloid $\beta$-peptide as linked phenomena in Alzheimer's disease. Neurochem Int 2001, 39:333-340.

53. Bacskai BJ, Kajdasz ST, Christie RH, Carter C, Games D, Seubert P, Schenk D, Hyman BT: Imaging of amyloid-beta deposits in brains of living mice permits direct observation of clearance of plaques with immunotherapy. Nat Med 2001, 7(Suppl 3):369-372.

54. Forman MS, Trojanowski JQ, Lee VM: Neurodegenerative diseases: a decade of discoveries paves the way for therapeutic breakthroughs. Nat Med 2010, 10(Suppl 10):1055-1063.

55. Wyss-Coray T, Loike JD, Brionne TC, Lu E, Anankov R, Yan F, Silverstein SC, Husemann J: Adult mouse astrocytes degrade amyloid-beta in vitro and in situ. Nat Med 2003, 9:453-457.

56. Wyss-Coray T: Inflammation in Alzheimer disease: driving force, bystander or beneficial response? Nat Med 2006, 12:1005-1015.

57. Maragakis NJ, Rothstein JD: Mechanisms of disease: astrocytes in neurodegenerative disease. Nat Clin Pract Neurol 2006, 2:679-689.

58. Mrak RE, Sheng JG, Griffin WS: Glial cytokines in Alzheimer's disease: review and pathogenic implications. Hum Pathol 1995, 26(Suppl 8):816-823.

59. Sheng JG, Mrak RE, Griffin WS: Microglial interleukin-1 alpha expression in brain regions in Alzheimer's disease: correlation with neuritic plaque distribution. Neuropathol Appl Neurobiol 1995, 21(Suppl 4):290-301.

60. Hickman SE, Allison EK, El Khoury J: Microglial dysfunction and defective beta-amyloid clearance pathways in aging Alzheimer's disease mice. J Neurosci 2008, 28:8354-8360.

61. Sierra A, Gottfried-Blackmore AC, McEwen BS, Bulloch K: Microglia derived from aging mice exhibit an altered inflammatory profile. Glia 2007, 55:412-424.

62. Akiyama H, Mori H, Saido T, Kondo H, Ikeda K, McGeer PL: Occurrence of the diffuse amyloid beta-protein (Abeta) deposits with numerous Abeta-containing glial cells in the cerebral cortex of patients with Alzheimer's disease. Glia 1999, 25:324-331.

63. Paresce DM, Chung H, Maxfield FR: Slow degradation of aggregates of the Alzheimer's disease amyloid $\beta$-protein by microglial cells. J Biol Chem 1997, 272:29390-29397.

64. Majumdar A, Chung H, Dolios G, Wang R, Asamoah N, Lobel P, Maxfield FR: Degradation of fibrillar forms of Alzheimer's amyloid $\beta$-peptide by macrophages. Neurobiol Aging 2008, 29:707-715.

65. Wisniewski HM, Vorbrodt AW, Wegiel J: Amyloid angiopathy and blood-brain barrier changes in Alzheimer's disease. Ann NY Acad SCi 1997, 826:161-172.

66. Wegiel J, Wang KC, Imaki H, Rubenstein R, Wronska A, Osuchowski M, Lipinski WJ, Walker LC, LeVine H: The role of microglial cells and astrocytes in fibrillar plaque evolution in transgenic APP(SW) mice. Neurobiol Aging 2001, 22:49-61.

67. Wegiel J, Imaki H, Wang KC, Wronska A, Osuchowski M, Rubenstein R: Origin and turnover of microglial cells in fibrillar plaques of APPsW transgenic mice. Acta Neuropathol 2003, 105:393-402.

68. Bocchini V, Mazzolla R, Barluzzi R, Blasi E, Sick P, Kettenmann H: An immortalized cell line expresses properties of activated microglial cells. J Neurosci Res 1992, 31:616-621.

69. Kopec KK, Carroll RT: Alzheimer's beta-amyloid peptide 1-42 induces a phagocytic response in murine microglia. J Neurochem 1998, 71:2123-2131.

70. Hirt UA, Leist M: Rapid, noninflammatory and PS-dependent phagocytic clearance of necrotic cells. Cell Death Differ 2003, 10:1156-1164.

71. Koenigsknecht J, Landreth G: Microglial phagocytosis of fibrillar beta-amyloid through a beta1 integrin-dependent mechanism. J Neurosci 2004, 24:9838-9846.

72. Cooper $\mathrm{PH}$, Mayer P, Baggiolini M: Stimulation of phagocytosis in bone marrow-derived mouse macrophages by bacterial lipopolysaccharide: correlation with biochemical and functional parameters. J Immunol 1984, 133:913-922.

73. DiCarlo G, Wilcock D, Henderson D, Gordon M, Morgan D: Intrahippocampal LPS injections reduce Abeta load in APP + PS1 transgenic mice. Neurobiol Aging 2001, 22:1007-1012

74. Streit WJ: Microglia and Alzheimer's disease pathogenesis. J Neurosci Res 2004, 77:1-8.

75. Itagaki S, McGeer PL, Akiyama H: Presence of T-cytotoxic suppressor and leucocyte common antigen positive cells in Alzheimer's disease brain tissue. Neurosci Lett 1988, 91:259-264.
76. Togo T, Akiyama H, Iseki E, Kondo H, Ikeda K, Kato M, Oda T, Tsuchiya K, Kosaka K: Occurrence of T cells in the brain of Alzheimer's disease and other neurological diseases. J Neuroimmunol 2002, 124:83-92.

77. Fiala M, Liu QN, Sayre J, Pop V, Brahmandam V, Graves MC, Vinters HV: Cyclooxygenase-2-positive macrophages infiltrate the Alzheimer's disease brain and damage the blood-brain barrier. Eur J Clin Invest 2002 32:360-371.

78. Ray S, Britschgi M, Herbert C, Takeda-Uchimura Y, Boxer A, Blennow K, Friedman LF, Galasko DR, Jutel M, Karydas A, Kaye JA, Leszek J, Miller BL, Minthon L, Quinn JF, Rabinovici GD, Robinson WH, Sabbagh MN, So YT, Sparks DL, Tabaton M, Tinklenberg J, Yesavage JA, Tibshirani R, Wyss-Coray T: Classification and prediction of clinical Alzheimer's diagnosis based on plasma signaling proteins. Nat Med 2007, 13:1359-1362.

79. Malm TM, Koistinaho M, Pärepalo M, Vatanen T, Ooka A, Karlsson S, Koistinaho J: Bone-marrow-derived cells contribute to the recruitment of microglial cells in response to beta-amyloid deposition in APP/PS1 double transgenic Alzheimer mice. Neurobiol Dis 2005, 18(Suppl 1):134-142.

80. Simard AR, Rivest $S$ : Neuroprotective effects of resident microglia following acute brain injury. J Comp Neurol 2007, 504(6):716-29.

81. Priller J, Flugel A, Wehner T, Boentert M, Haas CA, Prinz M, Fernandez-Klett F, Prass K, Bechmann I, de Boer BA, Frotscher M, Kreutzberg GW, Persons DA, Dirnagl U: Targeting gene-modified hematopoietic cells to the central nervous system: use of green fluorescent protein un- covers microglial engraftment. Nat Med 2001, 7:1356-1361.

82. Fiala M, Zhang L, Gan X, Sherry B, Taub D, Graves MC, Hama S, Way D, Weinand M, Witte M, Lorton D, Kuo YM, Roher AE: Amyloid- $\beta$ induces chemokine secretion and monocyte migration across a human blood-brain barrier model. Mol Med 1998, 4:480-489.

doi:10.1186/s12974-014-0161-z

Cite this article as: Majerova et al:: Microglia display modest phagocytic capacity for extracellular tau oligomers. Journal of Neuroinflammation 2014 11:161.

\section{Submit your next manuscript to BioMed Central and take full advantage of:}

- Convenient online submission

- Thorough peer review

- No space constraints or color figure charges

- Immediate publication on acceptance

- Inclusion in PubMed, CAS, Scopus and Google Scholar

- Research which is freely available for redistribution 